August 2007

\title{
Episodes from the Genocide of the Native Americans: A Review
}

\section{Essay}

Paul R. Bartrop

Follow this and additional works at: https://digitalcommons.usf.edu/gsp

\section{Recommended Citation}

Bartrop, Paul R. (2007) "Episodes from the Genocide of the Native Americans: A Review Essay," Genocide Studies and Prevention: An International Journal: Vol. 2: Iss. 2: Article 7.

Available at: https://digitalcommons.usf.edu/gsp/vol2/iss2/7

This Articles is brought to you for free and open access by the Open Access Journals at Digital Commons @ University of South Florida. It has been accepted for inclusion in Genocide Studies and Prevention: An International Journal by an authorized editor of Digital Commons @ University of South Florida. For more information, please contact digitalcommons@usf.edu. 


\title{
Episodes from the Genocide of the Native Americans: A Review Essay
}

\author{
Paul R. Bartrop \\ Head, Department of History, Bialik College, Melbourne, Victoria, \\ Australia
}

Vicki Rozema, ed. Voices from the Trail of Tears. Winston-Salem, NC: John F. Blair, 2003. Pp. 240, paper. \$11.95 US.

Stan Hoig. The Sand Creek Massacre. Norman: University of Oklahoma Press, 1961; reprint, 2006. Pp. 217, paper. \$19.95 US.

Jerome A. Green and Douglas D. Scott. Finding Sand Creek: History, Archaeology, and the 1864 Massacre Site. Norman: University of Oklahoma Press, 2004. Pp. 241, cloth. \$24.95 US.

Richard G. Hardorff, ed. Indian Views of the Custer Fight: A Source Book. Norman: University of Oklahoma Press, 2005. Pp. 237, paper. \$14.95 US.

Gary Clayton Anderson. The Conquest of Texas: Ethnic Cleansing in the Promised Land. Norman: University of Oklahoma Press, 2005. Pp. 494, cloth. \$29.95 US.

The genocide of indigenous peoples throughout the Americas represents one of the greatest and most extensive human catastrophes in history. The pace and magnitude of the destruction varied from region to region over the years, but it can safely be concluded that, in the two-and-a-half centuries following Christopher Columbus' "discovery" of the Americas in 1492, probably 95\% of the pre-Columbian population was wiped out-by disease as well as by deliberate policy on the part of the Spanish, the French, the English, and, ultimately, the American-born heirs of those colonizing nations.

The process of colonization was often characterized by violent confrontation, deliberate massacre, wholesale annihilation, and, in several instances, genocide. Many indigenous peoples in North America, for instance, were completely, or almost completely, wiped out, including the Yuki of California and the Beothuk of Newfoundland. It is important, therefore, that care be taken when employing the term "genocide" in the context of colonial expansion: each and every claim must be assessed individually and on its merits. In some instances, genocide might be unequivocal; elsewhere, despite a sudden or enormous population collapse, the crucial ingredient of the colonizers' intent would not appear to have been present. Often, populations declined as a result of diseases that arrived with the colonizers, and the deaths that occurred were not anticipated. On other occasions, lethal diseases were deliberately introduced for the purpose of wiping out a population. If we were to generalize - not an easy task over several centuries-it could be said that colonial

Paul R. Bartrop, "Episodes from the Genocide of the Native Americans: A Review Essay". Genocide Studies and Prevention 2, 2 (August 2007): 183-190. (C) 2007 Genocide Studies and Prevention. doi: $10.3138 / \mathrm{gsp} / 006$ 
expansion in North America saw attempts at clearing the land of indigenous populations; of forcibly assimilating these populations for racial, religious, or ethnic reasons; and of intimidating them so that they would seek to retreat before the advance of the colonizers, enabling Western-style economic development to take place.

Overall, we are looking at a horrific case (or, rather, series of cases) of mass human destruction, in which millions of people lost their lives. And the destruction did not stop once most of the people had died or been killed; in the United States, policies of population removal, dispossession of lands, forced assimilation, and confinement to "reservations" meant that, in a vast number of cases, even the survivors were denied the opportunity to retain their identity as distinct peoples.

The foundations of indigenous destruction were many, and they varied from place to place. The quest for land, religious conversion, the development of concepts of racial inferiority and superiority, displacement, and population transfer undertaken in the pursuit of "progress" on the frontiers of European or American settlement-all of these had their place in the devastation of the Native Americans. Individual murders, occasional massacres, and wholesale annihilation in long-term campaigns facilitated violent destruction. That genocide of specific Native American groups took place is beyond doubt; but this must be tempered by the qualification that not all destruction or population collapse occurred as the result of a deliberate intent on the part of the settlers. On those occasions where intent can be detected, a case for genocide might be prosecuted, but the disintegration of the Native American world was not a monolithic event, and it must, therefore, be examined carefully and thoroughly, with an eye to the particularity of each people, region, and period and without preconceived opinions.

The forced removal of the Native American peoples of the southeastern United States presents us with one such dilemma. Can this be considered a case of genocide? In 1830, US President Andrew Jackson signed the Indian Removal Act, a law ordering the compulsory relocation of Native American peoples living east of the Mississippi River to a designated territory to the west. These peoples, known as the "Five Civilized Tribes," were the Cherokee, Choctaw, Creek, Chickasaw, and Seminole Nations; they had adapted to European ways and taken the elements most suited to improving their quality of life while at the same time retaining their sovereign integrity and folkways. After the passage of the Indian Removal Act, however, they were forced to cede their lands to the United States and move to other territories many hundreds of miles away. Of the individual treaties signed following the Indian Removal Act, the first was between the United States and the Choctaw Nation, at Dancing Rabbit Creek in 1830. Between 1831 and 1834, most members of this nation were forced westward at the point of federal bayonets, and in appalling conditions; because federal expenditures for removal were inadequate, there were food shortages, unsatisfactory means of transportation, and little in the way of warm clothing or blankets. At least a quarter of the Choctaw Nation died before they reached the new Indian Territory in modernday Oklahoma.

A similar fate befell the other nations. In the case of the Creeks, a conflict resembling civil war broke out between supporters and opponents of removal. When the Creeks were ultimately "removed," just under a quarter of their population died of exposure and disease. Because of their closer proximity to the new Indian Territory, the Chickasaws suffered less on their actual journey, but they perished in large numbers after their arrival owing to disease. For as long as they were able, the Seminoles managed to resist removal, and during the Seminole Wars (1835-1842) they 
made US troops pay a heavy price for their invasion of the Seminole Nation. Nonetheless, several thousand were eventually transferred to the Indian Territory.

The Cherokees, the most numerous of the Five Civilized Tribes, did all they could to avoid deportation, arguing their case in the highest US tribunals, including the Senate and the Supreme Court, but by the Treaty of New Echota (signed on 29 December 1835), which ceded all Cherokee territory to the United States and prepared the grounds for removal, they too were forced to leave by 1839 . Approximately one-quarter of the Cherokees perished between 1838 and 1839 along what became known as the "Trail of Tears." The term now stands as a generic name for the forced removal and suffering of the Five Civilized Tribes, during which time tens of thousands of people died as a direct result of US government actions and failures to act.

In Voices from the Trail of Tears, Vicki Rozema, who has previously written on the history of the Cherokees, has compiled a source book that recounts the fate of those who undertook or observed the Cherokee Trail of Tears. In this book, the actual participants give us an insight into what happened during this infamous chapter in American history. Combining eyewitness accounts, letters from white missionaries and doctors describing the mistreatment of Cherokees at the hands of the federal troops and government officials, observations by federal soldiers, and other original sources, Rozema's work highlights the horror of the forced deportations for the participants and the shock of those who witnessed them.

Rozema presents her sources in chronological, rather than thematic, order, which shows clearly how the drama of the removals unfolded. Readers are thus exposed to a number of key areas pertaining to the period, one of the most important of which concerned dissent and hostility among Cherokees over the Treaty of New Echota and, indeed, the very issue of whether or not they would allow the Cherokee Nation, as a sovereign state, to be summarily removed by the United States government. The book then shows the removal policy in practice, with original accounts of how the Cherokee living in states such as Alabama, Georgia, North Carolina, and Tennessee were rounded up and sent on their way at the point of federal US bayonets. Finally, Rozema's documents illustrate that destruction can continue to take place long after the most dramatic events have ended, as readers are shown how difficult it was for those who survived the Trail of Tears to accept living in the new, alien territory of Oklahoma-a place occupied by other Native Americans who often had a very different perspective on the removals and those who managed to endure them.

The term "genocidal massacre" was introduced by noted political scientist and genocide scholar Leo Kuper in his seminal work on genocide in the twentieth century. ${ }^{1}$ Noting that the annihilation of a section of a group in a localized massacre (e.g., of a whole village of men, women, and children) contains some of the elements of a genocide, Kuper sought to find a way to give such massacres their proper place within a model of genocide while recognizing that such events do not, by themselves, constitute genocide. He thus found the notion of genocidal massacre particularly useful in describing colonial situations, identifying a clear affinity between colonialism and genocide. While even an aggregation of genocidal massacres does not necessarily indicate a policy of genocide, nonetheless the motives underlying such massacres were, in their circumstances of time and place, motivated by a genocidal intent. For Kuper, therefore, the genocidal massacre, while not equated with genocide, was a convenient device for explaining the many examples of destruction that took place during the process of territorial acquisition. 
One such genocidal massacre took place against the Cheyenne and Arapaho peoples of Colorado on 29 November, 1864 when the Third Colorado Volunteer Cavalry Regiment, under the command of Colonel John Chivington, led an attack against a Cheyenne village at Sand Creek. The Third Colorado Volunteers had signed on as Indian fighters, and over the previous two months, acting on Chivington's orders, they had rounded up small groups of Cheyenne and Arapaho for the purpose of killing them at a time to be determined later. Surrounding the Indian camp at Sand Creek before dawn on the morning of 29 November, the Third Colorado's assault group, comprising some 700 men and four howitzers, took their intended targets by complete surprise. Cheyenne Chief Black Kettle pleaded with his people to keep calm and hoisted both an American flag and a white flag of truce above his quarters, but to no avail. As the Cheyenne realized what was happening, the US troops opened fire; the ensuing massacre was so horrific that some of Chivington's own men would later give evidence against him for allowing such abhorrent acts to take place.

The soldiers were indiscriminate in their killing: men and women were scalped, pregnant women were ripped open, children were clubbed to death, and bodies were mutilated. No prisoners were taken, as this was intended to be a total annihilation. Any who did surrender were killed immediately, and the massacre continued for five miles beyond the Sand Creek campsite. When Chivington and the Third Colorado returned to Denver, they exhibited more than a hundred scalps, the gruesome booty of a death toll that may have numbered up to 200-of whom two-thirds were women and children, and nine were chiefs.

The massacre at Sand Creek was committed by perpetrators whose actions were not only explicit but eagerly advertised, with malice before the event and triumph after it. Moreover, it was committed by a military force raised by the government of the Colorado Territory for the express purpose of killing every Cheyenne on whom it could lay its hands. Chivington's orders came from the governor of Colorado, John Evans, and these orders were endorsed by a popular clamor throughout the territory. Sand Creek was clearly a genocidal massacre undertaken as part of a larger campaign of genocide against the Cheyenne and Arapaho, whose objective was that none would remain alive. It was, in its purest form, an act committed with intent to destroy, in whole or in part, a national (or ethnic, or racial) group through a deliberate policy of killing its members.

Several years ago, Stan Hoig produced what many regard as the definitive account of the Sand Creek Massacre, which has now been reprinted by the University of Oklahoma Press. Hoig's book, a moving epitaph to the Cheyenne Nation, has done justice to the historical record through its well written narrative style, meticulously documented throughout. Few readers could fail to be moved by some of the accounts in this book, and the same readers might well also feel immense anger and frustration as they witness actions that can only be described as inhumane and bloodthirstyactions, moreover, committed in the name of the very moral values upon which the United States was founded.

At the time Hoig was writing, however, there was a problem with writing about Sand Creek: the actual site of the village and the areas into which the massacre was pursued by the Third Colorado were hidden from sight, lost to time and legend. Across the century following 1864, efforts had been made to preserve the general vicinity, but the precise location of the massacre could not be found; all efforts to locate it failed. Finally, in 1998, the US Congress passed P.L. 105-243, the Sand Creek Massacre Site Study Act, which called for the National Parks Service, the state of Colorado, and the 
Cheyenne and Arapaho Nations to work together to locate the site. The location had to be pinpointed, it was felt, before the National Parks Service could assume guardianship in the future. The subsequent attempts to uncover the massacre site are related by Jerome Greene and Douglas Scott in Finding Sand Creek: History, Archeology, and the 1864 Massacre Site. This book is a detective story that adopts a multidisciplinary approach, employing historical and archaeological research techniques as well as tribal descriptions of the site. A number of pre-existing maps, created by earlier researchers, have also been consulted. The book is not a history of the massacre, in the manner of Hoig's volume, but, rather, an account of how the researchers managed to locate both the village and the surrounding field of operations undertaken by the Third Colorado Volunteers. While it is not, strictly speaking, a historical account that sheds any new light on the massacre itself, the project it describes is a significant one: not only will the site henceforth be preserved, but the Cheyenne and Arapaho nations can have a focus for memorialization and closure-and, perhaps, a measure of healing.

An episode in the Native American experience that seems never to have achieved closure is the Battle of the Little Bighorn, an armed engagement that took place on 25-26 June 1876 between a combined force of Lakota Sioux and Northern Cheyenne warriors and the US Seventh Cavalry near the Little Bighorn River in Montana Territory. The battle represented a remarkable victory for the Lakota and Cheyenne, as the Seventh Cavalry, under the command of General George Armstrong Custer, was annihilated. Ever since, historians in the United States and elsewhere have been reconsidering how it was that the troops of a modern army, just ten years after the Civil War, could have been defeated by what was at the time considered to be an inferior and primitive people. A number of advantages suggest, however, that the Seventh Cavalry found itself in a very difficult position even before the fighting began.

For a start, though it is difficult to determine precisely how large the Native American force was, it is usually held that they outnumbered the Seventh Cavalry by a ratio of at least three to one (and, at some stages of the battle, even more). In addition, some of the Indians were armed with rifles more advanced than those of the cavalrymen, while the very ground over which the battle was fought gave the Lakota and Northern Cheyenne an advantage. Custer's troops, moreover, were not seasoned soldiers skilled in combat conditions, and they were already in poor physical shape because of the lack of sleep and the reduced rations occasioned by the campaign. The battle, in short, was fought on terms set by those opposed to the Seventh Cavalry.

Of those serving in Custer's unit, sixteen officers and 242 troopers were killed or died of wounds, including Custer himself. After the battle, attempts were made to identify the dead, but most had been stripped of their clothing, mutilated, and left where they fell. When US forces entered the area later, they found it difficult to identify many of the bodies, and all were simply buried collectively. Another fifty-two cavalrymen who were wounded in the battle survived. It has not been accurately determined how many Native Americans died in the battle; estimates range from thirty-six (the oft-quoted Native American figure) up to as many as 300.

The Battle of the Little Bighorn quickly became part of western folklore in the United States, the subject of plays, novels, and academic studies. All too frequently, though, the voices of the Lakota Sioux and the Northern Cheyenne have been left out of the literature, appearing only in a stereotyped or token manner. In the third volume of Native American testimony about the Battle of the Little Bighorn, noted author Richard G. Hardorff has produced Indian Views of the Custer Fight: A Source Book, compiling thirty-eight interviews and statements from Native American eyewitnesses 
to the event. Here, twenty-nine Lakota Sioux and nine Northern Cheyenne detail events in their own words-extracted from letters, newspaper accounts, US Army reports, and manuscripts. Reproduced here as a series of statements, interviews, and narratives, these accounts make remarkable reading. While some of the interviews, for instance, are in a question-and-answer format, other accounts tell the story in a highly descriptive fashion. We learn from these accounts that Custer was not dealing with the typical "White Man's Indian," a "savage" given only to the basest of bloodthirsty impulses; rather, we see men in combat recounting strategy, motivations, and the respect they had for their foes. We even, on occasion, see the petty jealousies and gripes that can appear in any body of armed men acting under orders from those with whom they do not always agree. While Indian Views of the Custer Fight is not unique within the genre of Native American studies, it is, nonetheless, a marvelous resource for those seeking to understand something of the all-too-frequently forgotten "other side" of what has gone down in history as "Custer's Last Stand." It is both informative and inspirational, and a laudable addition to the literature of what happened on that fateful day in June 1876.

It is to be hoped that Hardorff pursues his interest in retrieving this form of testimony by following the subsequent destiny of the US Seventh Cavalry to the events at Wounded Knee Creek, South Dakota, on 29 December 1890. At that time, the Seventh Cavalry, still smoldering from its defeat at Little Bighorn fourteen years earlier, took the opportunity to settle accounts with the Sioux encamped at Wounded Knee. The subsequent massacre-which popular wisdom has preferred to label a battle, though it was so one-sided that this term is hardly appropriate-was the final confrontation in the three-century relationship between Native Americans and expansionist whites on what the latter referred to as "the frontier." The Sioux were cut down mercilessly. Four Hotchkiss guns surrounding the camp opened fire, scything through their victims like chaff. Less than an hour later, the fighting and killing had ended. Almost two-thirds of the Sioux were casualties-at least 200 dead and wounded were counted, though many others were not accounted for. The US Army lost twentyfive killed and thirty-nine wounded. The "battle" of Wounded Knee was a massacre of men, women, and children, the last major action of its kind in the course of the westward expansion of the United States.

Because genocide is a crime, academic literature about genocidal destruction is frequently accompanied by partisan acceptance or rejection on the part of victim or perpetrator populations. Sometimes serious academic scholarship is met by immediate and unequivocal denial from those on the receiving end of allegations that genocide was committed. Claims may be made about misquotation and the falsification of research findings, or evidence may be dismissed as inaccurate.

Such was the somewhat heated response to the appearance in 2005 of Gary Clayton Anderson's study The Conquest of Texas: Ethnic Cleansing in the Promised Land, 1820-1875. Anderson has written a highly detailed account of early Texas history; when it first appeared, however, many commentators, particularly within Texas itself, categorized it as little more than a new, "politically correct" view of Texas history biased against the white settlers who made the republic, then the state, what it is today. Others, in similar vein, took the book to be an attempt on Anderson's part to create a controversial and commercial reputation by interpreting well-known sources of Texas history in a biased way. Rather than a groundbreaking study of multicultural relations in early Texas, it was claimed, Anderson had instead produced a work 
proceeding from a flawed premise-namely, that the Native American perspective on early Texas history has never truly been appreciated or studied.

Anderson's primary thesis is that Anglo-Europeans and Spanish-speaking Texans (Tejanos) engaged in an organized conspiracy to drive the Native Americans from Texas, or to exterminate them. His book identifies an extensive and well-organized campaign carried out by the invaders, in which little quarter was given. This is a clearly revisionist work that contradicts much of the pre-existing literature on the development of Texas during the nineteenth century.

In seeking to establish his case and to demythologize the romance of Texas history, Anderson sometimes falls into traps he might better have avoided. There are occasions, for example, when he oversimplifies the complex events and political environment of Texas over his lengthy period of study-half a century during which monumental changes took place in a wide variety of areas.

Take, for example, Anderson's assessment of those allegedly responsible for much of the destruction, the Texas Rangers. He characterizes them as an out-of-control and bloodthirsty militia with few redeeming qualities, and in this they differed little from many of the irregular militias established for the purpose of securing US rule over territories claimed for white settlement— the Third Colorado Volunteers at Sand Creek are another example among many. Little is new about this assessment: the early Texas Rangers did indeed commit acts of barbarity on the frontier. Anderson's description of the Rangers as unrelenting and merciless killers, however, needs to be considered within the context of the evidence upon which he bases his claims. This consists largely of negative contemporary accounts produced by regular US Army officers who disapproved of the Rangers' military informality and apparent lack of discipline. According to such reports, the Texas Rangers lacked what would today be called "the warrior's honor," and for this they were often denigrated. Anderson, it would seem, has taken many of these accounts at face value, and in so doing has built his profile from a largely one-dimensional resource base. It would be interesting to learn whether a broader range of sources might yield a different picture of the Rangers.

Further, given his topic, Anderson is on sensitive ground when he introduces controversial terms such as "ethnic cleansing" and "concentration camps"-controversial owing to a lack of any sort of in-depth theoretical discussion of these twentieth century concepts in their relationship to nineteenth century events. Further, he concludes that although the Native Americans of Texas experienced ethnic cleansing, they did not experience genocide-which he defines, contrary to international law as defined in the 1948 UN Convention on the Prevention and Punishment of the Crime of Genocide, as "the intentional killing of nearly all of a racial, religious, or cultural group" (7).

Anderson's book is based on extensive research and a thorough recounting of detail; it brings out many fine points that have not previously seen the light of day, emanating from hard work in archives throughout the United States. Anderson's bias is too readily apparent to make this reviewer comfortable, however; it would have been preferable if he had allowed the total corpus of available evidence to speak for itself, rather than laboring the point as he sometimes does. Does The Conquest of Texas support its central thesis of a cohesive anti-Native conspiracy in early Texas? Superficially, it does, though a very close reading of the sources and context upon which the author bases his conclusions renders him vulnerable in a number of important areas. 
Colonialism is a form of control frequently characterized by the establishment of settler communities that result in the displacement, absorption, or destruction of preexisting indigenous communities. In the history of the United States, large numbers of settlers left their original homes to start new outgrowth communities or to reinforce those of their kin already there. In so doing, they took over-sometimes quite brutally-land already occupied by Native Americans. Genocidal massacres of the latter were not infrequent, and ongoing oppression or neglect has in numerous cases persisted to the present day. Colonialism, in its impact on Native American populations, also led to the suppression of local languages, religions, and folkways as the settlers looked for ways to consolidate their rule and ward off what they perceived as threats to the expansion of "their" territory in the new land. The human cost was devastating and long lasting for the Native American populations taken over by the colonizers, and the injury done to their sense of identity and self-worth has, in many cases, yet to be healed.

\section{Note}

1. Leo Kuper, Genocide: Its Political Use in the Twentieth Century (New York: Penguin, 1981). 